\title{
Penicillium notatum Antigen IgG4 Antibody Measurement
}

National Cancer Institute

\section{Source}

National Cancer Institute. Penicillium notatum Antigen IgG4 Antibody Measurement. NCI

Thesaurus. Code C130149.

A measurement of the Penicillium notatum antigen IgG4 antibody in a biological specimen. 